\title{
Developing and Implementing Nursing Guidelines to Improve Lifestyle Pattern for Vitiligo Patients
}

\author{
Asmaa Abd-ELSabour Saleh', Hala Mohammad Ghanem², Ayman Mohamed Mahran, Hanan Abd El-Razik \\ Abd El-all. \\ 1. Nursing Specialist, at Main Assiut Hospital at Infection Control, Egypt. \\ 2. Assistant Professor of Medical, Surgical Nursing Faculty of Nursing, Assuit University Egypt \\ 3. Assistant Professor of Dermatology and Venereology, Faculty of Medicine, Assuit University, Egypt. \\ 4. Lecturer of Medical Surgical Nursing, Faculty of Nursing, Assiut University Egypt.
}

\begin{abstract}
Vitiligo is a chronic disorder of the skin, characterized by progressive loss of melanocytes from the epidermis manifested as white macules or patches. This study aims to: Assess the effect of Nursing Guidelines on the life style pattern of patients with vitiligo. Research design: pre-post-test research design was utilized. Sample: this study included 40 adult patients with vitiligo their age between 18 to 60 years old and from both sexes. Setting: the study sample was recruited from the Dermatology Department, Assuit University Hospitals. Tools: three tools were used in this study: pre-post patient knowledge questionnaire sheet for healthy life style, and Pre-Post Patient Life Style Pattern Assessment Sheet for patients with vitiligo. Based on the result of the assessment phase nursing guidelines developed and implemented. Results: There was statistical significant difference between life style patterns pre-post the implementation of the nursing guidelines for patients with vitiligo. Conclusion: The study findings revealed that developing and implementing nursing guidelines based on the needs of patients with vitiligo were effective in improving their lifestyle.
\end{abstract}

\section{Keywords: Nursing Guidelines, Lifestyle Pattern \& Patients with Vitiligo.}

\section{Introduction}

Vitiligo is an acquired pigmentary disorder of unknown etiology that is clinically characterized by the development of white macules caused by selective loss of melanocytes (Baharvand, \& Aghdami, 2012). Vitiligo is one of the most common skin diseases and is characterized by the disappearance of the natural color of the skin. It can be focal or generalized (Yagil, 2017).

Vitiligo is caused by the loss of melanocytes, which are found naturally in the skin, hair follicles, mucous membranes and some parts of the central nervous system. The amount and quality of melanin cells is the essential determining factor of skin, hair and eyes color (Taieb et al., 2013).

Exact etiology of vitiligo is not yet defined .However genetic, autoimmune, neurological, oxidative stress and melanocytorrhagy theories have been implicated (David \& Prescilia, 2014). More than 50 worldwide epidemiologic studies reported that the worldwide prevalence generally lies within the range of $0.4-2 \%$ (Silverberg et al., 2015).

Lifestyle is defined as the way or manner by which people live their lives. This is often reflected in their activities, beliefs, interests, opinions and values, and influenced by certain factors such as family, culture and social status (Kaakinen et al., 2018). Lifestyle modification is appositive effect on vitiligo risk factors. Nursing guideline and health education regarding patient nutrition, physical activity and stress management can improve disease outcome (Nho, 2017).

Improving health lifestyle of patients with vitiligo had become a priority for health care provider with the overall objective of achieving a high degree of patient satisfaction through greater awareness among the patients, increasing demand for better care, keener competition, and more health care regulation, (Potter et al., 2016)

The healthy life style pattern of patients with vitiligo is essentially determined by the quality of infrastructure, quality of nursing guidelines, competence of personnel and efficiency of operational systems. The fundamental requirement is the adoption of a system that is 'patient orientated'. Existing problems in health lifestyle relate to both medical and non-medical factors and a comprehensive system that improves both aspects which must be implemented. Health care provider should developing patient lifestyle and recovers all knowledge and must be balanced with equal opportunities in nursing guidelines (Acton, 2012). 


\section{Significance of the study}

From the researchers clinical experience, it has been observed that vitiligo is one of cutaneous disorder Vitiligo can affect persons emotional and psychological well-being. Most of patients with vitiligo report several psychological problems, particularly if the disease is on exposed areas of the body. So this study will focus on the necessary nursing guidelines which can be helpful for such group of patient.

\section{Aim of the study}

This study aimed to assess the effect of nursing guidelines on the lifestyle pattern of patients with vitiligo.

\section{Hypothesis}

To fulfill the aims of the study the following research hypothesis will be formulated; lifestyle pattern of Patients with Vitiligo will be improved after the implementation of nursing guidelines.

\section{Subjects \& Methods \\ Research design}

A quiz - experimental research design with one group (Pre/Post-test) approach was utilized to conduct this study.

\section{Setting}

The study was conducted in the ultraviolet unit at the Dermatology Department of Assuit University Hospitals from October 2017 until May 2018

\section{Patients}

The study was included (40) patients clinically diagnosed with vitiligo their age ranged from 18 to 60 years old (male and female).

\section{Study tools}

Three tools were used in this study and were collected, utilized and developed by the researcher as the following:-

Tool (I): Pre-Post patient knowledge questionnaire sheet for healthy life style pattern:

This sheet designed and developed by the researcher based on current national and international literature (walker et al., 2014) to assess patient knowledge about health life style pattern, it consists of two parts

\section{Part 1: Patient socio-demographic characteristic}

This part was developed to assess socio demographic characteristics of the patient (age, gender, address, marital status, level of education, occupation, economic status, status of home, body weight, also the time \&history of disease. It included 11 items (question from 1 to 11 ).

\section{Part 2: Patient's knowledge about vitiligo}

It was developed by the researcher based on current national and international literature review (Oguz et al., 2016) to asses patient's knowledge about vitiligo .It included (27) items. Questions from 1 to 27about vitiligo including definition of vitiligo, autoimmune disease , melanocytes, types of vitiligo, causes ,classifications, clinical manifestations, diagnosis, treatment and nursing guidelines to improve health life style patterns for vitiligo patients

Scoring system

The total number of questions was (38) .It was used before to implementation of the nursing guidelines to measure the exact knowledge level of patients about vitiligo. The same tool was used immediately after the implementation of the nursing guidelines (immediate post /test) to evaluate the gain in knowledge after the guideline. Each item was categorized and scored into either:

Yes $=(2$ scores $) \quad \mathrm{No}=(0)$.

The total score for all items was (76) score

- Satisfactory level of knowledge $>70 \%$

- Unsatisfactory level of knowledge $<70 \%$ (onianwa et al., 2017).

Toole (II): -Pre/Post Patient Life Style Pattern Assessment Sheet (PLSPAS) for Vitiligo:

This tool was identified a way of living or the manner in which people conduct their day to day activates. This tool was developed by (walker et al., 2014) to assess and evaluated the life style pattern of patient with vitiligo. The tool was translated, modified, and adapted to the Egyptian culture by the researcher related to Egyptian patients with vitiligo. The researcher was guided and advice by the supervisors and advice of the experts in medical and nursing field. It included the following 6 parts:

Part (1) Physical activity: it included 8 items( from 1 to 8)cover the following items: period of exposure to sun, work hazer exposure, perform heavy work , activities daily living, practice exercise, duration 1 day, smoking habits, sleep and rest pattern.

Part (2): Dietary pattern assessment it was included 17 items cover the following:

eating regular three meals \& regular protein amount, zinc diet ,eat food contain vitamin D, folic acid \& B12, fibers, , vegetable, avoid excess salt, drink 6 cups of water daily, avoid eat fast food, take antioxidant drink, eat health food and weight measure (Questions from 1 to 17 ).

Part (3): Health aspect assessment: it include12 items (from 1 to 12) over the following items: regularly consult physician when recent symptom appear, do investigations, discuss health problems related vitiligo with other, observe changes in skin , attend health programs about vitiligo, read books, take prescribed medications and comply to medications.

Part (4): Psychological aspect assessment and stress management: it include 9 items from 1 to 9 cover the following items: complain from stressor, being aware of stress sources, daily relation time, 
sleeping at day, meditation, self-way management of stress (1 to 9).

Part (5): Social support assessment: it include 8 Question (from 1 to 8 ) cover the following items: isolation time, keep social relations, spend time with friends, express feelings to others, share problem concerns with others patient or member, share others concerns, vitiligo did not affect social life, look for new people relation.

Part (6) Self-concept assessment: it include11 items (from1 to 11)

cover the following items: had good spiritual relation with God do not feel illness is punishment from God, do not feel different due to illness, feel no change in being respected by others, had good spiritual life, have good hopes, feel self-satisfied, have future goals, do not feel illness is an obstacle, do not face difficulties due vitiligo, do not face difficulties due illness.

This question sheet was administered by the researcher to the patients to answer its entire component then collected. The total number of questions was 66 items. It was used before to implementation of the nursing guidelines to assess and evaluated the life style pattern about vitiligo. The same tool was used after the implementation of the nursing guidelines (post /test) to evaluate the gain in knowledge after the guidelines.

\section{Scoring system}

The total number of questions was (66). Each item was categorized and scored into either:

Always $=(2) \quad$ Sometimes $=(1) \quad$ Never $=(0)$

The total score for all items was (130) scores

Those who obtained less than $(50 \%)$ were considered having unhealthy lifestyle pattern

From (50\% to $70 \%)$ were considered having satisfactory healthy lifestyle pattern.

While those who obtained have than $(70 \%)$ were considered having good healthy lifestyle pattern.

Toole (III): Developing nursing guidelines for vitiligo patient

This tool developed by the researcher based on patients' needs assessment, literature review, research experience and opinions of the medical and nursing expertise. Nursing guidelines was revised and modified based on the expertise comments; it was written in Arabic using simple language with illustrations. It was concerning nursing guidelines for vitiligo and consisted of the following:

- Definition of vitiligo, types, nature of the disease , causes, classification, clinical manifestation, diagnoses, and vitiligo treatment.

- Nursing guidelines about melanocytes, healthy physical activity pattern behavior, healthy dietary pattern behavior, psychological and stress management.
Content validity and reliability

The content validity was done by panel of 5 experts ( 3 specialist in medical- surgical nursing and 2 experts in medical field) from Assiut University Hospital their reviewed the instruments for clarity, relevance, comprehensiveness, understanding, applicability and competence for administrative, was done minor modifications. Tool's reliability: refers to the degree of consistency with which the questionnaire measure the thing it is supposed to be measured patients knowledge and pattern. Reliability of tools was confirmed by Alpha Cronbach test (0.95).

\section{Pilot study}

A pilot study carried out in September until October 2017 to test clarity, completeness, feasibility and practicability of the study tools on $10 \%$ of sample. It had also provided an estimate of time needed to fill out the tools. The purposes of the pilot study were to detect any particular problem in the statements clarity, feasibility, and applicability of the tools. Analyses of the pilot study revealed that minimal modifications are required. These modifications were done and the subjects were not excluded from the actual study sample.

\section{Ethical considerations}

1. Research proposal were approved from Ethical Committee in the faculty of nursing.

2. There is no risk for study subject during application of research.

3. The study was followed common ethical principles in clinical research.

4. Oral consent was be obtained from patients or guidance that were Participated in the study, after explained the nature and purpose of the study.

5. Confidentiality and anonymity will be assured.

6. Study subject have the right to refuse to participate and /or withdraw from the study without any rational at any time.

7. Study subject privacy was considered during data collection.

\section{Statistical analysis}

The data obtained had reviewed, prepared for computer entry, coded, analysed and tabulated. Descriptive statistics (frequencies and percentages, means and standard deviation, i.e.) were done using computer program (SPSS) version (22). Independent sample $\mathrm{T}$ test, Chi-square and One-way-ANOVA tests used in relationship between patients' (pre \& post) knowledge. Improbability level of (0.05) was adopted as level of significance for testing the research hypothesis. 


\section{Results}

Table (1): Percentage distribution of the socio demographic characteristics of the studied patients $(N=40)$

\begin{tabular}{|c|c|c|}
\hline Items & Frequency & $\%$ \\
\hline \multicolumn{3}{|l|}{ Age group } \\
\hline $20<30$ years & 18 & 45.0 \\
\hline $30<40$ years & 11 & 27.5 \\
\hline $40<50$ years & 4 & 10.0 \\
\hline $50-60$ years & 7 & 17.5 \\
\hline Mean \pm SD & \multicolumn{2}{|c|}{$35.57 \pm 14.41$} \\
\hline \multicolumn{3}{|l|}{ Sex } \\
\hline Female & 21 & 52.5 \\
\hline Male & 19 & 47.5 \\
\hline \multicolumn{3}{|l|}{ Address } \\
\hline Rural & 32 & 80.0 \\
\hline Urban & 8 & 20.0 \\
\hline \multicolumn{3}{|l|}{ Marital status } \\
\hline Single & 18 & 45.0 \\
\hline Married & 21 & 52.5 \\
\hline Divorced & 1 & 2.5 \\
\hline \multicolumn{3}{|l|}{ Level of education } \\
\hline Illiterate & 16 & 40.0 \\
\hline Secondary & 18 & $\overline{45.0}$ \\
\hline University & 6 & 15.0 \\
\hline \multicolumn{3}{|l|}{ Occupation } \\
\hline officer & 5 & 12.5 \\
\hline Handwork & 6 & 15.0 \\
\hline Hard work & 2 & 5.0 \\
\hline Free work & 27 & 67.5 \\
\hline
\end{tabular}

Table (2): comparison between physical behavior pattern pre/post implementation of nursing guidelines as regard vitiligo: $\mathbf{N}=\mathbf{4 0}$.

\begin{tabular}{|c|c|c|c|c|c|c|c|c|c|}
\hline \multirow{3}{*}{ Physical behaviors } & \multicolumn{4}{|c|}{ Pre test } & \multicolumn{4}{|c|}{ Post test } & \multirow{3}{*}{ p.value } \\
\hline & \multicolumn{2}{|c|}{ Yes } & \multicolumn{2}{|c|}{ No } & \multicolumn{2}{|c|}{ Yes } & \multicolumn{2}{|c|}{ No } & \\
\hline & $\mathbf{N}$ & $\%$ & $\mathbf{N}$ & $\%$ & $\mathbf{N}$ & $\%$ & $\mathbf{N}$ & $\%$ & \\
\hline Exposure to sun during $10 \mathrm{am}: 2 \mathrm{pm}$ & 28 & 70.0 & 12 & 30.0 & 1 & 2.5 & 39 & 97.5 & $.001 *$ \\
\hline Exposure to Phenol & 2 & 5.0 & 38 & 95.0 & 0 & 0.00 & 40 & 100.0 & $.247^{\mathrm{ns}}$ \\
\hline Performing heavy work & 30 & 75.0 & 10 & 25.0 & 29 & 72.5 & 11 & 27.5 & $513^{\mathrm{ns}}$ \\
\hline Needing rest during work & 16 & 40.0 & 24 & 60.0 & 8 & 20.0 & 32 & 80.0 & $.001 * *$ \\
\hline Changing in sleeping pattern & 6 & 15.0 & 34 & 85.0 & 1 & 2.5 & 39 & 97.5 & $.001 * *$ \\
\hline Smoking & 7 & 17.5 & 31 & 77.5 & 5 & 12.5 & 35 & 85.0 & $.025^{*}$ \\
\hline Trying to quit smoking & 1 & 2.5 & 2 & 5.0 & 5 & 12.5 & 35 & 85,0 & $.001 * *$ \\
\hline
\end{tabular}

Use Pearson chi-square $\quad * *=$ highly significance $\quad$ Ns $=$ Non significant difference $(P$ value $<0.05)$ 
Table (3): Comparison between dietary life style pattern pre and post implementation of the guidelines about vitiligo $\mathbf{N}$. $=40$.

\begin{tabular}{|c|c|c|c|c|c|c|c|c|c|c|c|c|c|}
\hline \multirow{3}{*}{ Dietary pattern } & \multicolumn{6}{|c|}{ Pre } & \multicolumn{6}{|c|}{ Post } & \multirow{3}{*}{$\begin{array}{l}\text { p. } \\
\text { value }\end{array}$} \\
\hline & \multicolumn{2}{|c|}{ Always } & \multicolumn{2}{|c|}{ sometimes } & \multicolumn{2}{|c|}{ absolutely } & \multicolumn{2}{|c|}{ Always } & \multicolumn{2}{|c|}{ sometimes } & \multicolumn{2}{|c|}{ Absolutely } & \\
\hline & $\mathrm{N}$ & $\%$ & $\mathrm{~N}$ & $\%$ & $\mathrm{~N}$ & $\%$ & $\mathrm{~N}$ & $\%$ & $\mathrm{~N}$ & $\%$ & $\mathrm{~N}$ & $\%$ & \\
\hline $\begin{array}{l}\text { Take meal three } \\
\text { time daily }\end{array}$ & 23 & 57.5 & 17 & 42.5 & 0 & 0 & 35 & 87.5 & 5 & 12.5 & 0 & 0 & $.003 * *$ \\
\hline $\begin{array}{l}\text { Take meal rich } \\
\text { with protein }\end{array}$ & 15 & 37.5 & 24 & 60.0 & 1 & 2.5 & 33 & 82.5 & 7 & 17.5 & 0 & $0.0 \%$ & $.001 * *$ \\
\hline $\begin{array}{l}\text { Take meal rich } \\
\text { with Zinc }\end{array}$ & 12 & 30.0 & 26 & 65.0 & 2 & 5.0 & 34 & 85.0 & 6 & 15.0 & 0 & 0.00 & $.001 * *$ \\
\hline \multicolumn{14}{|c|}{ known Zinc source } \\
\hline Chicken \&beef & 19 & 47.5 & - & - & - & - & 12 & 30.0 & - & - & - & - & \multirow{4}{*}{$451^{\mathrm{Ns}}$} \\
\hline Sea food. & 1 & 2.5 & - & - & - & - & 1 & 2.5 & - & - & - & - & \\
\hline Baked beans & 4 & 10.0 & - & - & - & - & 5 & 12.5 & - & - & - & - & \\
\hline all of above & 16 & 40.0 & - & - & $\overline{--}$ & - & 22 & 55.0 & - & - & - & - & \\
\hline $\begin{array}{l}\text { Take meal rich } \\
\text { vitamin D }\end{array}$ & 8 & 20.0 & 27 & 67.5 & 5 & 12.5 & 29 & 72.5 & 10 & 25.0 & 1 & 2.5 & $.001 * *$ \\
\hline \multicolumn{14}{|c|}{ known vitamin D source } \\
\hline Fish & 14 & 35.0 & - & - & - & - & 17 & 42.5 & - & - & - & - & \multirow[t]{4}{*}{$.048^{\mathrm{NS}}$} \\
\hline Yolk & 12 & 30.0 & - & - & - & - & 15 & 37.5 & - & - & - & - & \\
\hline Liver & 14 & 35.0 & - & - & - & - & 5 & 12.5 & - & - & - & - & \\
\hline cream & 0 & 0.00 & - & - & - & - & 3 & 7.5 & - & - & - & - & \\
\hline $\begin{array}{l}\text { Take meal rich } \\
\text { vitamin B12 }\end{array}$ & 10 & 25.0 & 28 & 70.0 & 2 & 5.0 & 36 & 90.0 & 3 & 7.5 & 1 & 2.5 & $.001 * *$ \\
\hline \multicolumn{13}{|c|}{ known vitamin B12 source } & \multirow{4}{*}{$.160^{\mathrm{Ns}}$} \\
\hline Milk & 14 & 35.0 & - & - & - & - & 21 & 52.5 & - & - & - & - & \\
\hline Egg & 8 & 20.0 & - & - & - & - & 8 & 20.0 & - & - & - & - & \\
\hline Liver \& meat & 12 & 30.0 & - & - & - & - & 12 & 30.0 & - & - & - & - & \\
\hline
\end{tabular}

Table (4): Comparison between pre and post nursing guidelines regarding psychological assessment of studied patients: N.40.

\begin{tabular}{|c|c|c|c|c|c|c|c|c|c|c|c|c|c|}
\hline \multirow{3}{*}{$\begin{array}{l}\begin{array}{c}\text { Psychological } \\
\text { assessment }\end{array} \\
\begin{array}{l}\text { Suffer from } \\
\text { psychological stress }\end{array}\end{array}$} & \multicolumn{6}{|c|}{ Pre-test } & \multicolumn{6}{|c|}{ Post-test } & \multirow{3}{*}{$\begin{array}{c}\begin{array}{c}\text { p. } \\
\text { value }\end{array} \\
.001^{* *}\end{array}$} \\
\hline & \multicolumn{2}{|c|}{ Always } & \multicolumn{2}{|c|}{ Sometimes } & \multicolumn{2}{|c|}{ absolutely } & \multicolumn{2}{|c|}{ Always } & \multicolumn{2}{|c|}{ sometimes } & \multicolumn{2}{|c|}{ absolutely } & \\
\hline & 22 & $55.0 \%$ & 12 & $30.0 \%$ & 6 & 15.0 & 1 & 2.5 & 27 & 67.5 & 12 & 30.0 & \\
\hline $\begin{array}{l}\text { Aware of stressor } \\
\text { sources }\end{array}$ & 22 & $55.0 \%$ & 10 & $25.0 \%$ & 8 & 20.0 & 36 & 90.0 & 3 & 7.5 & 1 & 2.5 & $.002 * *$ \\
\hline \multicolumn{13}{|l|}{ Stressor sources : } & \multirow{8}{*}{$\begin{array}{l}0.001 * \\
*\end{array}$} \\
\hline Family problems & 16 & $40.0 \%$ & - & - & - & - & 1 & 2.5 & - & - & - & - & \\
\hline work problems & 6 & $15.0 \%$ & - & - & - & - & 6 & $15.0 \%$ & - & - & - & - & \\
\hline Health problems & 2 & $5.0 \%$ & - & - & - & - & 0 & $0.0 \%$ & - & - & - & - & \\
\hline Economic problem & 5 & $12.5 \%$ & - & - & - & - & 5 & $12.5 \%$ & - & - & - & - & \\
\hline $\begin{array}{l}\text { Family problems \& } \\
\text { health problems }\end{array}$ & 21 & $52.5 \%$ & - & - & - & - & 9 & $22.5 \%$ & - & - & - & - & \\
\hline $\begin{array}{l}\text { Health problems \& } \\
\text { economic problem }\end{array}$ & 7 & $17.5 \%$ & - & - & - & - & 7 & $17.5 \%$ & - & - & - & - & \\
\hline All of the above & 4 & $10.0 \%$ & - & - & - & - & 0 & $0.0 \%$ & - & - & - & - & \\
\hline $\begin{array}{l}\text { Adequate time to } \\
\text { relaxation } \\
\text { \&meditation }\end{array}$ & 4 & $10.0 \%$ & 19 & $47.5 \%$ & 17 & $42.5 \%$ & 26 & $65.0 \%$ & 12 & $30.0 \%$ & 2 & $5.0 \%$ & $.001 * *$ \\
\hline $\begin{array}{l}\text { Adequate time to } \\
\text { rest or sleep in } \\
\text { afternoon }\end{array}$ & 10 & $25.0 \%$ & 17 & $42.5 \%$ & 13 & $32.5 \%$ & 26 & $65.0 \%$ & 13 & $32.5 \%$ & 1 & $2.5 \%$ & $.001 * *$ \\
\hline Easy to fall asleep. & 9 & $22.5 \%$ & 24 & $60.0 \%$ & 7 & $17.5 \%$ & 36 & $90.0 \%$ & 4 & $10.0 \%$ & 0 & $0 \%$ & .001 ** \\
\hline
\end{tabular}


Table (5): Comparison between pre and post nursing guidelines regarding social assessment of studied patients: N. 40.

\begin{tabular}{|c|c|c|c|c|c|c|c|c|c|c|c|c|c|}
\hline \multirow{3}{*}{ Social pattern } & \multicolumn{6}{|c|}{ Pre-test } & \multicolumn{6}{|c|}{ Post- test } & \multirow[t]{3}{*}{$\begin{array}{c}\text { p. } \\
\text { value }\end{array}$} \\
\hline & \multicolumn{2}{|c|}{ Always } & \multicolumn{2}{|c|}{ sometimes } & \multicolumn{2}{|c|}{ Absolutely } & \multicolumn{2}{|c|}{ Always } & \multicolumn{2}{|c|}{ sometimes } & \multicolumn{2}{|c|}{ Absolutely } & \\
\hline & $\mathbf{N}$ & $\%$ & $\mathbf{N}$ & $\%$ & $\mathbf{N}$ & $\%$ & $\mathbf{N}$ & $\%$ & $\mathbf{N}$ & $\%$ & $\mathbf{N}$ & $\%$ & \\
\hline Living isolated & 6 & 15.0 & 15 & 37.5 & 19 & 47.5 & 2 & 5.0 & 13 & 32.5 & 25 & 62.5 & $.228 \mathrm{~ns}$ \\
\hline $\begin{array}{l}\text { Maintain good relationship } \\
\text { with other }\end{array}$ & 15 & 37.5 & 21 & 52.5 & 4 & 10.0 & 35 & 87.5 & 3 & 7.5 & 2 & 5.0 & $.00 * *$ \\
\hline $\begin{array}{l}\text { Stay a lot of time with } \\
\text { relative \& friends }\end{array}$ & 21 & 52.5 & 17 & 42.5 & 2 & 5.0 & 34 & 85.0 & 6 & 15.0 & 0 & .0 & $.006^{* *}$ \\
\hline $\begin{array}{l}\text { Explain your emotion } \\
\text { \&sensation to others }\end{array}$ & 12 & 30.0 & 15 & 37.5 & 13 & 32.5 & 29 & 72.5 & 10 & 25.0 & 1 & 2.5 & $.001 * *$ \\
\hline $\begin{array}{l}\text { Feel happiness when others } \\
\text { participated }\end{array}$ & 24 & 60.0 & 14 & 35.0 & 2 & 5.0 & 38 & 95.0 & 2 & 5.0 & 0 & 0.0 & $.001 * *$ \\
\hline $\begin{array}{l}\text { Participating others with } \\
\text { problems }\end{array}$ & 13 & 32.5 & 22 & 55.0 & 5 & 12.5 & 34 & 85.0 & 4 & 10.0 & 2 & 5.0 & $.001 * *$ \\
\hline $\begin{array}{l}\text { concerns others to } \\
\text { psychological support }\end{array}$ & 7 & 17.5 & 12 & 30.0 & 21 & 52.5 & 23 & 57.5 & 14 & 35.0 & 3 & 7.5 & $.001 * *$ \\
\hline $\begin{array}{l}\text { Feel happens with others } \\
\text { communication }\end{array}$ & 18 & 45.0 & 18 & 45.0 & 4 & 10.0 & 37 & 92.5 & 2 & $5.0 \%$ & 1 & 2.5 & $.001 * *$ \\
\hline
\end{tabular}

Use Pearson chi-square $\quad * *=$ highly significance $\quad N s=$ Non significant difference $(P$ value $<0.05)$

Table (6): Comparison between pre and post nursing guidelines regarding self- concept of studied patients: $\mathbf{N}$. $=40$.

\begin{tabular}{|c|c|c|c|c|c|c|c|c|c|c|c|c|c|}
\hline \multirow{3}{*}{ Self-concept } & \multicolumn{6}{|c|}{ Pre-test } & \multicolumn{6}{|c|}{ Post-test } & \multirow[t]{3}{*}{ p. value } \\
\hline & \multicolumn{2}{|c|}{ Always } & \multicolumn{2}{|c|}{ sometimes } & \multicolumn{2}{|c|}{ Absolutely } & \multicolumn{2}{|c|}{ Always } & \multicolumn{2}{|c|}{ sometimes } & \multicolumn{2}{|c|}{ Absolutely } & \\
\hline & $\mathbf{N}$ & $\%$ & $\mathbf{N}$ & $\%$ & $\mathbf{N}$ & $\%$ & $\mathbf{N}$ & $\%$ & $\mathbf{N}$ & $\%$ & $\mathbf{N}$ & $\%$ & \\
\hline Good relation with God & 24 & 60.0 & 14 & 35.0 & 2 & 5.0 & 37 & 92.5 & 2 & 5.0 & 1 & 2.5 & $.002 * *$ \\
\hline $\begin{array}{l}\text { Feel to disease is afflicting } \\
\text { from God }\end{array}$ & 33 & 82.5 & 5 & 12.5 & 2 & 5.0 & 31 & 77.5 & 8 & 20.0 & 1 & 2.5 & $.58 \mathrm{~ns}$ \\
\hline Feeling different about others & 7 & 17.5 & 13 & 32.5 & 20 & 50.0 & 1 & 2.5 & 1 & 2.5 & 38 & 95.0 & $.001 * *$ \\
\hline $\begin{array}{l}\text { People respect differently after } \\
\text { disease }\end{array}$ & 3 & 7.5 & 15 & 37.5 & 22 & 55.0 & 1 & 2.5 & 3 & 7.5 & 36 & 90.0 & $.002 * *$ \\
\hline $\begin{array}{l}\text { Hope to live happy living and } \\
\text { expect good from God }\end{array}$ & 19 & 47.5 & 15 & 37.5 & 6 & 15.0 & 37 & 92.5 & 1 & 2.5 & 2 & 5.0 & $.000 * *$ \\
\hline Feel self-Satisfy & 22 & 55.0 & 12 & 30.0 & 6 & 15.0 & 36 & 90.0 & 1 & 2.5 & 3 & 7.5 & $.001 * *$ \\
\hline $\begin{array}{l}\text { Feel with enthusiasm } \\
\text { \&optimism in your live }\end{array}$ & 19 & 47.5 & 18 & 45.0 & 3 & 7.5 & 35 & 87.5 & 3 & 7.5 & 2 & 5.0 & $.000 * *$ \\
\hline Goals can you achieving & 21 & 52.5 & 14 & 35.0 & 5 & 12.5 & 33 & 82.5 & 5 & 12.5 & 2 & 5.0 & $.016^{*}$ \\
\hline Determine your goal & 18 & 45.0 & 15 & 37.5 & 7 & 17.5 & 31 & 77.5 & 4 & 10.0 & 5 & 12.5 & $.006^{* *}$ \\
\hline $\begin{array}{l}\text { Feel disease traverse to achieve } \\
\text { goals }\end{array}$ & 3 & 7.5 & 14 & 35.0 & 23 & 57.5 & 1 & 2.5 & 0 & 0.0 & 39 & 97.5 & $.001 * *$ \\
\hline $\begin{array}{l}\text { Meeting hardness because } \\
\text { disease. }\end{array}$ & 3 & 7.5 & 9 & 22.5 & 28 & 70.0 & 1 & 2.5 & 1 & 2.5 & 38 & 95.0 & $.012 *$ \\
\hline
\end{tabular}

Use Pearson chi-square $* *=$ highly significance

Table (1): Showed that; the majority of patient's their ages were ranged from 20 to less than 30 years old $(45.0 \%)$ with mean age $(35.57 \pm 14.41)$ years. The majority of them were female $(52.5 \%)$, live in rural area (80.0\%), Married (52.5), Secondary school education $(45.0 \%)$, deferent free work $(67.5 \%)$.

Table (2): Showed that there was a statistical significance difference between pre and post implementation of the nursing guidelines as regarding physical behavior assessment.

Table (3): Showed that there was statistical significant difference between dietary life style patterns in pre /post implementing guidelines about vitiligo.
$N s=$ Non significant difference $(P$ value $<0.05)$

Table (4): Showed that there was statistical significant difference between pre and post nursing guidelines regarding psychological assessment of the studied sample.

Table (5): Showed that there was statistical significant difference between pre and post nursing guidelines regarding social life style pattern of the studied sample.

Table (6): Showed that there was statistical significant difference between pre and post nursing guidelines regarding self-concept assessment of the studied sample.

\section{Discussion}


Vitiligo is an acquired, idiopathic disorder characterized by depigmented macules that result from damage or selective destruction of melanocytes (Iannella et al., 2016).

Nurses are important health care providers of the vitiligo patient to ensure that the patient is educated. The nurse should encourage the patients for medical compliances, as vitiligo is considered as chronic disorder with variable response to treatment (Halder et al., 2011).

The present study included (40) patients clinically diagnosed with vitiligo, their most ages were ranged from 20 to less than 30years old. This result was in compatibles with (Daneshpazhooh et al., 2006) who said that the mean ages of vitiligo patients were ranged from 25 to 30 years old. But (Silverberg J \& Silverberg, 2013) had an opposite opinion regarding the finding of his study that founded that vitiligo was a disease can occur at any age. This was in accordance with Sinani et al., (2015) who reported that no significant difference in age of onset of vitiligo between the two sexes.

In our study we found that the females gender was more affected than males, This was in accordance with Jha, (2015) who found that the incidence of vitiligo was higher among females gender. This may be attributed to the fact that females are more concerned by the disease and its distressing appearance more than males, leading to an increased and earlier presentation of females to dermatology clinics. In addition, autoimmune diseases are more common among females.

Regarding to patients' residence; the majority of the study sample were from rural area and more than half were married. This result agreed with Almomani et al., 2015) who found that the most affected patient with vitiligo were from rural regions. Also that same line with (Dolatshahi, et al., 2008) who found that the most affected vitiligo patient were from married patient both male and female.

Regarding physical behavior lifestyle assessment the present study showed that there was a statistical significance difference between pre and post guidelines .This result agreed with (Tamesis, and Morelli, 2010) Who found that; change in patient with vitiligo physical behavior lifestyle as sunlight exposure has been reported to arrest disease progression in $(64 \%)$ of patients in his study, and achieve varying degrees of repigmentation up to $(100 \%)$ in about half of patients.

But this result were disagreed with (Dunlap et al., 2018) who found an associations between reactions to excessive hot sun exposure and risk of vitiligo incident.

In addition the present study showed that heavy physical movements as heard work is a risk for spreading vitiligo .This result agreed with (Yoon et al., 2011) who found a repetitive movements in exercise or work can induce vitiligo due to trauma or friction with certain body areas and the patient should consider modifying this work area or discontinuing the exercise.

This study showed there was statistical significant difference between level of the studied patient's knowledge in pre / post implementation of the nursing guidelines as regard to physical pattern this agreed with (Taïeb et al., 2013), who said that the location of vitiligo can give clues as to its triggers or causes. In stress-induced cases, skin lesions are frequently localized to the seborrheic area. In traumatic types, the lesions are usually localized to sites of injury or pressure.

Regarding assessment of the dietary lifestyle pattern; The result of the present study reveal that; there was a statistical significant deference between pre and post implementation of the nursing guidelines regarding dietary lifestyle pattern .This agree with (Jalel et al, 2009), who studied has demonstrated that the level of vitamin B12, folic acid, copper, and zinc in patients with vitiligo may be lower than in unaffected individuals. Microelements such as selenium, copper, and zinc are essential in the diet or as supplements. It is preferable to take vitamin B12 along with folic acid due to the considerable synergistic effects of the pairing. But this disagreed with (Ravish, 2011) who mentioned that; Diet is not considered very important factor in the treatment of vitiligo. However, a healthy, balanced diet with nutrients from a variety of sources can be helpful in vitiligo treatment.

Regarding assessment of psychosocial life style pattern; the present study reported that the majority of the study suffers from isolation, anxiety psychological stress. This compatible with (Wang et al., 2012) \& (Pahwa et al., 2013) who found that vitiligo patients suffer from social and emotional consequences like low self-esteem, worry, social anxiety, depression, stigmatization, in extreme cases, rejection by others. The study finding was agree with (Whitton et al., 2015), who said that patient those affected by vitiligo who is stigmatized for their condition may experience depression and similar mood disorders. This result was opposite with (Daniel \& Sivanesan, 2017) who found that, psychiatric morbidity was also unrelated to the vitiligo disease.

Regarding social-assessment pattern; the present study showed that there was statistical significant deference between pre and post nursing guidelines. This result was in the same line with (Salman et al., 2016) who mentioned that; vitiligo commonly affecting the face, have significant psychosocial 
effects and impair the quality of life of the affected individuals. Because of their negative effect on physical appearance, these conditions may act as a potential barrier to social relationships and cause social anxiety.

Regarding self-assessment concept; the study finding showed that there was statistical significant deference between pre and post nursing guidelines, this agreed with (VanGeel et al., 2016) who found that; excellent correlation with patient self-assessment and speeds of vitiligo (Validation of the SelfAssessment) may be useful in daily lifestyle practice. Also this agrees with (Picardi et al., 2013) who said the self-body image was influenced by perceived vitiligo severity and disease characteristics. Perceived severity and patient personality were predictors of life style impairment.

\section{Conclusion}

Based on the results of the present study, it can be concluded that:

There was a highly statistical significant difference between total score of patients with vitiligo lifestyle pattern in pre and post implementation of the nursing guidelines with $=(\mathrm{P}=0.001)$.

\section{Recommendation}

Continuous education program and educational booklets are provided should be planed and offered on regular basis for the patients and their family to explain the nature and effect of the disease.

\section{References}

1. Acton A., (2012): comprehensive information about medical research, Issues in Discovery, Experimental, and Laboratory Medicine Scholarly editions, ,Ch.8 P.138.

2. Almomani, N., Abdulmajeed, I., Ur Rahman, S., \& Alakkam, A., (2015): Quality of Life and Affective Health of Patients with Vitiligo. Vol.4, No. 2, P.3.

3. Baharvand, H., \& Aghdami, N., (2012): genetic skin disease, Regenerative Medicine and Cell Therapy, Springer company,ch.4, P.62.

4. Daneshpazhooh M., Mostofizadeh M., Behjati J, Akhyani M., \& Robati R.,(2006): Antithyroid peroxidase antibody and vitiligo: a controlled study, Vol.6, No.3, Pp.89-91.

5. Daniel, S., \& Sivanesan, A., (2017): Dermatological Quality of Life and Psychiatric Morbidity among Vitiligo patients, Vol 5, No.3, Pp.86-92.

6. David C., \& Prescilia I., (2014): The pathogenesis of vitiligo, Journal of the Egyptian Women's Dermatologic Society, Vol 11 - Issue 3 ,P p. 145-158.
7. Dolatshahi M., Ghazi P., Feizy V., Hemami M., (2008): Life quality assessment among patients with vitiligo: Comparison of married and single patients ,Iran.,Vol.74,No.6, Pp. 70-74.

8. Dunlap, R., Wu, S., Wilmer, E., Cho, E., Li, W., Lajevardi, N., \& Ebrahim, A., Hamed, A., Ahmed, E., \& Khudhair, A., (2018): Pigmentation Traits, Sun Exposure, and Risk of Incident Vitiligo in Women. Journal of Investigative Dermatology, 137(6), 1234-1239.

9. Halder R., Taliaferro S., Wolff K., Goldsmith L., \& Katz S., (2011): Dermatology in General Medicine, Vitiligo 7th ed. United States of America, McGraw Hill Medical, Vol.17,No.2, Pp. 616-621.

10. Iannella, G., Greco, A., Didona, D., Didona, B., Granata, G., Manno, A., \& Magliulo, G., (2016): Vitiligo: pathogenesis, clinical variants and treatment approaches. Autoimmunity reviews, vol.15, No.4, Pp.335-343.

11. Jalel, A., Soumaya, G., \& Hamdaoui, M., (2009): Vitiligo treatment with vitamins, minerals and polyphenol supplementation. Indian $\mathbf{J}$ Dermatol. Vol.54, No.4, Pp357-360.

12. Jha B., (2015): Assessment of prevalence of clinical and sociodemographic study of vitiligo Janaki Medical College, Nepal, Ch.1, Pp.1-4.

13. Kaakinen. J., Coehlo, D., Steele. R., \& Robinson, M., (2018): Family health care nursing: Theory practice and research, Family health promotion, FA Davis company, $6^{\text {th }}$ edition, Ch.6, P.149.

14. Nho. H., (2017): Journal of Lifestyle Medicine ,lifestyle intervention for obese women. National Library of Medicine, Vol.7, No.2, Pp.51-54.

15. Oguz I., Duman H., Kocaturk O., Durmuscan M., Gungor S., \& Ulkumen P., (2016):

Knowledge, beliefs, and perceptions of Turkish vitiligo patients regarding their condition, An Bras Dermatol, Vol. 91, No.6, Pp. 770-775.

16. Onianwa P., Along T., Otegbayo J., Ike E., Chukura F., Are O., Akanbi F., Ayorinde M., Adubi I., \& Yaya O., (2017): Pain as 5thvital sign impactof pain assessment training program on Nigirian nurses knowledge of pain Management. International Journal of Nursing and Midiwife, Vol.9, Pp.129-135.

17. Pahwa, P., Mehta, M., Khaitan, B., Sharma, V., \& Ramam, M., (2013): The psychosocial impact of vitiligo in Indian patients. Indian Journal of Dermatology, Venereology, and Leprology, Vol.79, No.5, P.679.

18. Picardi A., Pasquini P., Cattaruzza M., Gaeteno P., Melchi C., Baliva G., Camaioni D., Yiago A., Abeni D., \& Biondi M., (2013): Stressful life event, social support, attachment 
sequrity and alexithymia in vitiligo, Psychotherapy and psycociosmotic, Vol.72, No.3, Pp. 150-158).

19. Potter, A., Perry, G., Stocker, P., Hall, P., (2016): complete guide to nursing providing, a nursing process framework, Fundamentals of Nursing, Elsevier company ,9th edition ,Ch. 3,Pp.258-260.

20. Ravish, K., (2011): Vitiligo diet, In: Ayurhealthline, Vitiligo-Diet. REGOINAL Heath for Europe ,Vol.22, No.8, P.169.

21.Salman, A., Kurt, E., Topcuoglu, V., \& Demircay, Z., (2016): Social anxiety and quality of life in vitiligo and acne patients with facial involvement: a cross-sectional controlled study. American journal of clinical dermatology, Vol.17, No.3, Pp.305-311.

22.Silverberg J., \& Silverberg, N., (2013): Association between vitiligo extent and distribution and quality-of-life impairment. J. dermatology, Indian journal of dermatology, vol.149, No.24, Pp 159-164.

23. Silverberg N., (2015): The Epidemiology of vitiligo. Cur Dermatology, Vol. 4, No.1, Pp. 3643.

24. Sinani A., Roshi E., Lico R., (2015): A study on the prevalence and dermatology life quality index on vitiligo in Tirana, Albania. Balkan Mil Med Rev, Vol.18, No.3 ,Pp.106-115.

25. Taieb A., Alomar A., Bo “hm M., Dell'Anna M., De Pase A., Eleftheriadou, V., Ezzedine.K., Gauthier, Y., Gawkrodger D., Jouary T., Leone, G., Moretti S., Nieuweboer-Krobotova. L., Olsson M., Parsad, D., Passeron T., Tanew, A, Vander.veen W., Van, Geel N., Whitton M., Wolkerstorfer A., \& Picard, M., (2013): Guidelines for the management of vitiligo: the European Dermatology Forum consensus, Vol.3, No.1, Pp.5-19.

26. Tamesis, M., \& Morelli, J., (2010): Vitiligo treatment state of the art review. Dermatology J., Vol.27, No.5, Pp. 437-445.

27. VanGeel N., Lommerts J., Bekkenk M., Prinsen C., Eleftheriadou V., Taieb A., \& Speeckaert R., (2016): Validation of the SelfAssessment Vitiligo Extent Score (SA-VES) as a patient reported outcome. Journal of Investigative Dermatology, Vol.136, No.9, P.168.

28. Walker B., colledge N., Ralston S., \& Penman I., (2014): Assessment and management of clinical problem,ch18, principle and practice of medicine22th., Elsevier Limited,P.604.

29. Wang K., Wang K., Zhang Z., (2012): Healthrelated quality of life and marital quality of vitiligo patients in China. J Eur Acad Dermatol Venereol. Vol. 25, No.4, Pp.429-435.

30. Whitton, M., Pinart, M., Batchelor, J., Leonardi-Bee, J., González, U., Jiyad, Z., Eleftheriadou, V., Ezzedine, K., (2015): "Interventions for vitiligo". The Cochrane database of systematic 2nd edition, Issue.5, P.87.

31. Yagil, R., (2017): Cosmeceuticals: Camel and Other Milk-Natural Skin Maintenance. In Recent Advances in Drug Delivery Technology, vol.5,No.1, Pp. 309-338.

32. Yoon, J., Sun, Y., \& Kim, T., (2011): Complementary and Alternative Medicine for Vitiligo, Korea, ch. 10, Pp.140-159 